\title{
Predictive capability of response surface methodology and cybernetic models for cyanogenic simultaneous nitrification and aerobic denitrification facilitated by cyanide-resistant bacteria
}

\author{
Ncumisa Mpongwana ${ }^{1,4}$, Seteno Karabo Obed Ntwampe ${ }^{2^{\dagger}}$, Lovasoa Christine Razanamahandry ${ }^{3}$, \\ Boredi Silas Chidi ${ }^{4}$, Elizabeth Ife Omodanisi ${ }^{4,5}$ \\ ${ }^{1}$ Research and Postgraduate Support Division, Durban University of Technology Tromso Annexe, Steve Biko Campus, 1334, Durban 4000, South Africa \\ ${ }^{2}$ School of Chemical and Minerals Engineering, North-West University, Private Bag X1290, Potchefstroom, 2520, South Africa \\ ${ }^{3}$ African Union Development Agency, Economic Integration Division, Johannesburg, 1685, South Africa \\ ${ }^{4}$ Bioresource Engineering Research Group (BioERG), Faculty of Applied Sciences, Cape Peninsula University of Technology, 652, Cape Town, 8000, \\ South Africa \\ ${ }^{5}$ Department of Biological Sciences, Mountain Top University, Ogun State 110106, Nigeria
}

\begin{abstract}
Free cyanide $\left(\mathrm{CN}^{-}\right)$is a threat to metabolic functions of the microbial population used for the treatment of wastewater, particularly, total nitrogen removal (TN) consortia which gets inhibited by $\mathrm{CN}^{-}$in wastewater treatment plants (WWTPs). Many other methods are used to treat $\mathrm{CN}^{-}$prior to the TN removal stages; however, these methods increase the operational cost of the WWTPs. The capability of a microbial population to use multiple substrates is critical in WWTP and in eliminating inhibition associated with $\mathrm{CN}^{-}$. Previously, cyanide resistant bacteria were used to eliminate the inhibitory effect of $\mathrm{CN}^{-}$towards simultaneous nitrification and aerobic denitrification (SNaD). However, a study to predict the degradation efficiency of the microorganism was required. In this study, response surface methodology (RSM) and cybernetic models were used to predict and optimize $\mathrm{SNaD}$ performance for $\mathrm{TN}$ removal under $\mathrm{CN}^{-}$conditions. Physiological parameters influencing the $\mathrm{SNaD}$ were $\mathrm{pH}$ 6.5 and $36.5^{\circ} \mathrm{C}$, with $\mathrm{TN}$ and $\mathrm{CN}^{-}$degradation efficiency of 78.6 and $80.2 \%$, respectively. These results show a complete elimination of the CN inhibitory effect towards $\mathrm{SNaD}$ and show the prediction ability of both RSM and the cybernetic models used. These results exhibited a promising solution in the control, management, and optimization of $\mathrm{SNaD}$.
\end{abstract}

Keywords: Aerobic denitrification, Cybernetic model, Free cyanide, Nitrification, Response surface methodology (RSM), Simultaneous nitrification and aerobic denitrification $(\mathrm{SNaD})$

\section{Introduction}

The growth of a microorganism under multiple carbon source conditions can influence its performance even in large-scale wastewater treatment plants (WWTPs) [1-3]. Similarly, wastewater can be composed of different nitrogenous compounds from several industries. Current methods to treat this type of wastewater consist of traditional two-stage biological processes known as aerobic nitrification and anoxic denitrification. These treatment processes have different operating conditions and requirements such as dissolved oxygen concentration, carbon source requirements, and retention time, with throughput rates of the wastewater being treated in the processes being of utmost importance. Due to high energy consumption associated with the second reactor dedicated to anoxic denitrification, some studies have indicated the possibility of simultaneous nitrification and aerobic denitrification (SNaD) [4]. This process is advantageous than traditional nitrification after denitrification, providing for cost-effectiveness [5-7]. Moreover, $\mathrm{SNaD}$ is a highly effective method for total nitrogen (TN), i.e. ammonium nitrogen $\left(\mathrm{NH}_{4}-\mathrm{N}\right)$, nitrate-nitrogen $\left(\mathrm{NO}_{3}-\mathrm{N}\right)$,

Received June 19, 2020 Accepted November 30, 2020

${ }^{\dagger}$ Corresponding author

Email: Karabo.Ntwampe@nwu.ac.za

Tel: +27182991762

ORCID: 0000-0001-7516-6249 
and nitrite-nitrogen $\left(\mathrm{NO}_{2}-\mathrm{N}\right)$, removal from wastewater [8]. However, the microorganism(s) used during TN removal are highly sensitive to toxicant loadings, particularly free-cyanide ( $\left.\mathrm{CN}^{-}\right)$, thus, $\mathrm{SNaD}$ is the least effective of industrial wastewater treatment methods owing to a high concentration of contaminants that may completely inhibit $\mathrm{SNaD}$ [9-11]. Some remedial strategies such as activated carbon and chemical treatment have been used as a pretreatment step to combat the effect of $\mathrm{CN}^{-}$on TN removal. Similarly, activated carbon has been reported to have low adsorption capability towards $\mathrm{CN}^{-}$[12]. Furthermore, this additional step increases the operational cost of WWTPs associated with the operation of an additional reactor dedicated to the pretreatment of $\mathrm{CN}^{-}$. Thus, biological treatment methods, are recommended as a sustainable strategy to resolve the inhibitory effects of $\mathrm{CN}^{-}$ in TN removal [12].

The type of wastewater containing $\mathrm{CN}$ may result in serious environmental contamination and other challenges associated with its disposal if not treated [13-15]. Kim et al. [5] have reported that $\mathrm{CN}^{-}$possess the highest inhibitory effect on $\mathrm{SNaD}$. Previously, $\mathrm{CN}^{-}$inhibition has been eradicated by biological, physical, and chemical pretreatment methods [16]. These methods have been reported to increase operational costs associated with the operation of multiple reactors for pretreatment of the wastewater before $\mathrm{SNaD}$. Hence, some studies have proposed the application of cyanide degrading bacteria for $\mathrm{SNaD}$ to eliminate the inhibitory effect of $\mathrm{CN}^{-}$towards $\mathrm{SNaD}$, which can further reduce operational costs associated with the reactor designated for biological pretreatment of $\mathrm{CN}^{-}$[17] and for downstream denitrification.

Mpongwana et al. [18] and Han et al. [19] recommended the application of $\mathrm{CN}^{-}$degrading bacteria for TN removal from wastewater containing a high quantity of $\mathrm{CN}^{-}$as an alternative to mediate the effect of $\mathrm{CN}^{-}$on $\mathrm{SNaD}$. Other researchers have also recommended this strategy as a sustainable solution to $\mathrm{SNaD}$ inhibition by $\mathrm{CN}^{-}[20,21]$. Moreover, the application of cyanide degrading bacteria will not only resolve the inhibitory effect of $\mathrm{CN}^{-}$towards $\mathrm{SNaD}$, it will also resolve the challenge of slow-growing microorganisms responsible for $\mathrm{SNaD}$ since cyanide degrading bacteria have higher growth rates [22, 23]. This will likely improve process performance and compensate for biomass washout. Also, some cyanide degrading bacteria have been reported to also possess other important genes that are responsible for polyhydroxyalkanoates (PHA) synthesis which can serve as a carbon source during the cyanide degradation process [24]. This is another advantageous trait of cyanide degrading bacteria.

Mpongwana et al. [25], also reported a complete eradication of $\mathrm{CN}^{-}$inhibition towards $\mathrm{SNaD}$ by using a cyanide resistant $A$. courvalinii; however, the presence of $\mathrm{CN}^{-}$reduces the degradation rate of TN. Thus, this study aims to optimize TN removal by $A$. courvalinii under $\mathrm{CN}$ conditions. The presence of $\mathrm{CN}^{\top}$ compound alters the metabolic functions of microbial populations [5]; however, modelling approaches used to model single staged uninhibited $\mathrm{SNaD}$ systems may not adequately represent $\mathrm{SNaD}$ as a process on an industrial scale, particularly when potent inhibitors such as $\mathrm{CN}^{-}$are readily prevalent in TN containing wastewater. Hence, it is imperative to study the predictive ability of response surface methodology (RSM) which is a commonly used optimization and performance predictive software including a metabolic network model which also considers the metabolic functions of the microbial population since $\mathrm{CN}^{-} / \mathrm{SNaD}$ is an enzyme facilitated process.

\section{Materials and Methods}

The methodological flowchart for this study is illustrated in Fig. 1. The first step involves the isolation of different bacterial strains ( $\mathrm{n}=16$ ) from $\mathrm{CN}^{-}$containing wastewater, followed by determining their resistance to varying concentrations of $\mathrm{CN}^{-}$and $\mathrm{NH}_{4} \mathrm{NO}_{3}$ [26]. Some strains $(n=4)$ were found to be able to grow under high concentrations of $\mathrm{CN}^{-}$and ammonium. However, a single strain was found to be able to grow and utilize both $\mathrm{CN}^{-}$and $\mathrm{TN}$ as nitrogenous sources in a simulated SaND process. RSM was then used to determine the optimum conditions, with further reductions to the optimum quadratic model generated being implemented to adequately describe the process under study. Subsequently, $\mathrm{CN}^{-}$ and TN degradation kinetics experiments ensued using the optimum conditions obtained from the RSM, followed by cytoplasm extraction for application in enzyme kinetics. Similarly, a cybernetic model was developed and used to predict the rate of $\mathrm{CN}^{-}$and TN degradation as well as enzyme kinetics. After the conclusion of these experimental steps, the process prediction using models developed were regressed using polymath 6.0.

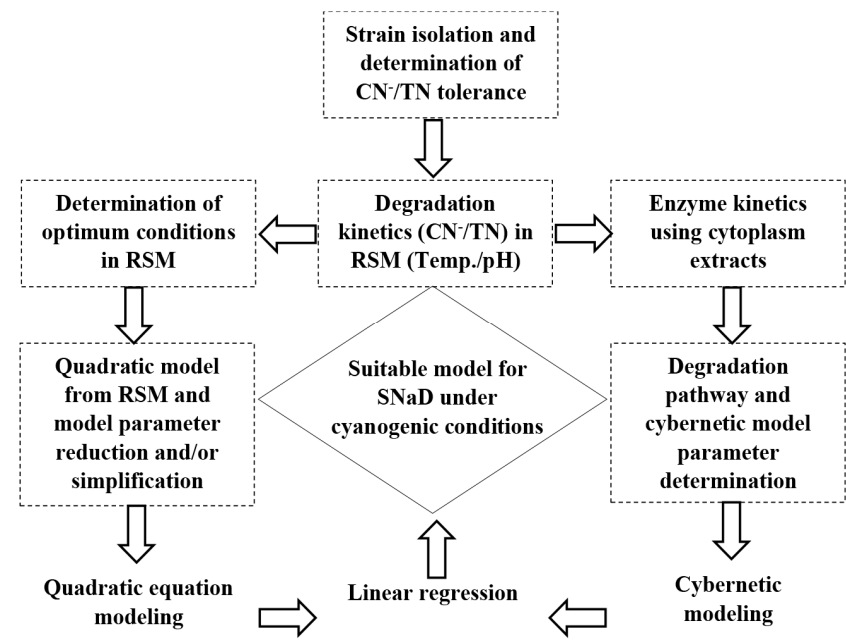

Fig. 1. Methodological flow chart for modelling of $\mathrm{SNaD}$ under $\mathrm{CN}^{-}$ conditions.

\subsection{Microbial Isolation and Identification}

The bacteria used for this study was isolated from $\mathrm{CN}^{-}$containing waste at the Bioresource Engineering Research Group (BioERG) facility at the Cape Peninsula University of Technology (CPUT), South Africa. Isolates were cultured on nutrient agar to obtain pure colonies. Thereafter, they were grown on nutrient agar (NA) containing different concentrations ranging from 10 to $300 \mathrm{mg}$ $\mathrm{CN}^{-} / \mathrm{L}$ to determine the highest concentration of $\mathrm{CN}^{-}$tolerance, after gram staining. The selected cyanide tolerant bacteria's $16 \mathrm{~S}$ RNA was sequenced and the bacteria was identified as A. courvalinii (accession number AB602910.1 or NR_148843.1) [27]. 


\subsection{Response Surface Methodology}

\subsubsection{Central composite design experiments}

The central composite design was used for the optimization of $\mathrm{SNaD}$ under $\mathrm{CN}^{-}$conditions. This was done by determining the independents' variables, i.e. temperature and $\mathrm{pH}$, optima which have been reported to affect $\mathrm{SNaD}$ [28]. In this study, a 13-run experimental plan which included the variation in independent variables (temperature and $\mathrm{pH}$ ) was generated using central composite design (CCD) (see Table S1).

The experimental design used for this study is shown in Table S2, with the corresponding response being primarily TN removal and $\mathrm{CN}^{-}$degradation. Synthetic wastewater containing $20 \mathrm{mg} \mathrm{NH}_{4} \mathrm{~N}$ $/ \mathrm{L}$ and $20 \mathrm{mg} \mathrm{CN}^{-} / \mathrm{L}$ were used for these experiments. The isolated strain was grown in a $250 \mathrm{~mL}$ multiport Erlenmeyer flask with $40 \mathrm{~mL}$ basal media containing: $1.5 \mathrm{~g} \mathrm{KH}_{2} \mathrm{PO}_{4}, 7.9 \mathrm{~g} \mathrm{Na}_{2} \mathrm{HPO}_{4}, 0.5$ $\mathrm{g} \mathrm{MgSO}_{4} .7 \mathrm{H}_{2} \mathrm{O}$ and $1 \mathrm{~mL}$ of trace elemental solution per litre. The trace element solution contained (per litre): 50 g EDTA, $2.2 \mathrm{~g}$ $\mathrm{ZnSO}_{4} .7 \mathrm{H}_{2} \mathrm{O}, 5.5 \mathrm{~g} \mathrm{CaCl}_{2}, 5.06 \mathrm{~g} \mathrm{MnCl}_{2} .4 \mathrm{H}_{2} \mathrm{O}, 5.0 \mathrm{~g} \mathrm{FeSO}_{4} .7 \mathrm{H}_{2} \mathrm{O}$, $1.1 \mathrm{~g}\left(\mathrm{NH}_{4}\right)_{6} \mathrm{Mo}_{7} \mathrm{O}_{2} .4 \mathrm{H}_{2} \mathrm{O}, 1.57 \mathrm{~g} \mathrm{CuSO}_{4} .5 \mathrm{H}_{2} \mathrm{O}$, $1.61 \mathrm{~g} \mathrm{CoCl}_{2} .6 \mathrm{H}_{2} \mathrm{O}$. The isolate was allowed to grow for $24 \mathrm{~h}$ before the addition of toxicants; $\mathrm{KCN}$ as $\mathrm{CN}^{-}$and $\mathrm{NH}_{4} \mathrm{SO}_{4}$ as $\mathrm{NH}_{4}-\mathrm{N}$.

The Erlenmeyer flasks that were used for this experiment had a sealable sampling port to avoid volatilization of $\mathrm{CN}^{-}$. After the addition of the toxicant, each experiment was monitored for 5 $\mathrm{h}$, and samples were taken after every $1 \mathrm{~h}$ to analyse for $\mathrm{CN}$, and $\mathrm{TN}$ as $\mathrm{NH}_{4}-\mathrm{N}, \mathrm{NO}_{2}-\mathrm{N}$, and $\mathrm{NO}_{3}-\mathrm{N}$, using Merck test kits and a Merck Spectroquant. All the experiments were done in duplicates with control experiments that did not contain the microorganism to account for the volatilization of $\mathrm{CN}^{-}$and $\mathrm{NH}_{4}-\mathrm{N}$ stripping. To determine the critical points (maximum, minimum, target, or within range) a polynomial function that contains quadratic terms were used (Eq. (1)) [29].

$$
y=\beta_{0}+\sum_{i=1}^{k} \beta_{i} X_{i}+\sum_{i=1}^{k} \beta_{i i} X_{i}^{2}+\sum_{1<i<j}^{k} \beta_{i j} X_{i} X_{j}+\varepsilon
$$

Where $k$ is the number of variables, $\beta_{0}$ is the constant term, $\beta \mathrm{i}$ is the coefficients of the linear parameters, $\beta_{\mathrm{ij}}$ is the coefficients of the interaction parameters, $\beta_{\mathrm{ii}}$ is the coefficients of the quadratic parameter, $x_{i}$ represents the variables, and $\varepsilon$ is the residual associated with the experiments.

\subsubsection{Data handling}

All the experiments were conducted in duplicates and the mean were calculated according to Eq. (2), thereafter the data was computed into Microsoft Excel 2016.

$$
\text { Mean }=\frac{\sum x}{n}
$$

Where $\sum X$ is the sum of all the duplicated data points. While $n$ is the number of data points. Standard deviation and variance were obtained from RSM and Polymath respectively. Standard deviation was calculated from variance using Eq. (3).

$$
s=\sqrt{\sigma}
$$

Where $\mathrm{s}$ and $\sigma$ are standard deviation and variance, respectively

\subsubsection{Statistical analyses}

The statistical analyses were centred on the lack of fit test which describes the fitness of mean and reduced the quadratic model of TN removal and the sequential model sum of squares. The model as represented in Eq. (1) indicated the relationship between the dependent variables and TN removal efficiency by the isolate in $\mathrm{CN}^{-}$containing wastewater. Furthermore, the significance of each variable in the model was analysed using Analysis of Variance (ANOVA) with a Multiple Regression Analysis being used to analyse the experimental data obtained.

\subsection{Cybernetic Model}

\subsubsection{Batch culture experiment}

A basal media similar to that used for the RSM experiments was used in batch cultures; although, the experiment was carried out in $1 \mathrm{~L}$ reactors. The media was inoculated with $100 \mathrm{~mL}$ of an overnight grown culture $(24 \mathrm{~h})$ incubated at optimum conditions determined by RSM, i.e. $36.5^{\circ} \mathrm{C}$, and a media $\mathrm{pH}$ of 6.5 . The culture was incubated for $168 \mathrm{~h}$ before the supplementation of $40 \mathrm{mg} \mathrm{CN} / \mathrm{L}$ and $250 \mathrm{mg}$ $\mathrm{NH}_{4}-\mathrm{N} / \mathrm{L}$; a combination that was shown to have little growth inhibition during toxicity assessments, with $2 \mathrm{~mL}$ samples being taken periodically ( $24 \mathrm{~h}$ intervals) for analyses, i.e. $\mathrm{CN}, \mathrm{NH}_{4}-\mathrm{N}, \mathrm{NO}_{2}-\mathrm{N}$, and $\mathrm{NO}_{3}-\mathrm{N}$. Enzymes, assumed to have been produced extracellular, were extracted using cold acetone daily from the cultures, to quantify maximum enzyme activity $\left(e_{i}^{\max }\right)$.

\subsubsection{Enzyme activity assessments}

The suspended bacterial cells in samples were removed by centrifuging each sample at 5,000 g for $5 \mathrm{~min}$; thereafter, to the cell-free supernatant, cold acetone was added, forming a cytoplasm precipitate, herein referred to as the enzyme extract, which was then separated from the supernatant by centrifugation at $16,000 \mathrm{~g}$ for $15 \mathrm{~min}$. The precipitate was washed $(\mathrm{n}=3)$ and initially stored at $-18{ }^{\circ} \mathrm{C}$ prior to re-suspension in $360 \mathrm{mg} / \mathrm{L}$ phosphate buffer solution ( $\mathrm{pH}$ 7.4). $\mathrm{NH}_{4}-\mathrm{N}$ and $\mathrm{CN}^{-}$solutions with an initial concentration of $10 \mathrm{mg} / \mathrm{L}$ for each contaminant were prepared and the enzyme extract was added into the solution, while the changes in $\mathrm{CN}^{-}$(09701), $\mathrm{NH}_{4}-\mathrm{N}$ (00683), $\mathrm{NO}_{2}-\mathrm{N}$ (110057), and $\mathrm{NO}_{3}-\mathrm{N}$ (14773) were monitored throughout the experiment.

\subsubsection{Analytical procedures}

All the test kits used for the analysis of the samples were obtained from Merck SA ( Merck Pty Ltd, Modderfontein, South Africa). Furthermore, a Merck Spectroquant Nova 60 instrument was used to analyse residual $\mathrm{CN}^{-}, \mathrm{NH}_{4}-\mathrm{N}, \mathrm{NO}_{2}-\mathrm{N}$, and $\mathrm{NO}_{3}-\mathrm{N}$. The basis of the individual assays is described elsewhere [30]. The kits were used as per the manufacturer's instructions.

\subsubsection{Model development}

A simplified model for the prediction of $\mathrm{SNaD}$ as well as $\mathrm{CN}^{-}$degradation in a single reactor was developed as shown in Fig. 2.

Two nitrogenous compounds $\mathrm{NH}_{4}-\mathrm{N}$ and $\mathrm{CN}^{-}$were used as pollutants with $\mathrm{S}_{1}$ and $\mathrm{S}_{2}$ presenting $\mathrm{NH}_{4}-\mathrm{N}$ which is assimilated none-enzymatically into the cell and $\mathrm{CN}^{-}$respectively, while $\mathrm{M}_{1}, \mathrm{M}_{2}$, and $\mathrm{M}_{3}$, represented intermediates, $\mathrm{NH}_{4}-\mathrm{N}, \mathrm{NO}_{2}-\mathrm{N}$, and $\mathrm{NO}_{3}-\mathrm{N}$ 


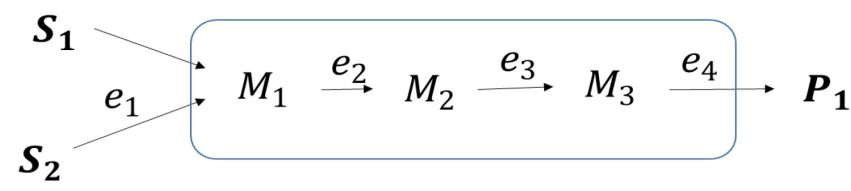

Fig. 2. Simplified metabolic network diagram of $\mathrm{SNaD}$ under cyanide-laden conditions. Key: $S_{1}: N_{4}-N, S_{2}: C N, M_{1}: N H_{4}-N, M_{2}: N O_{2}-N$, $M_{3}: N O_{3}-N$, and $P_{1}: N_{2}$.

respectively. The biomass used was deemed capable of using both $\mathrm{NH}_{4}-\mathrm{N}$ and $\mathrm{CN}^{-}$as primary pollutants to be degraded. The biomass converts $\mathrm{CN}^{-}$into $\mathrm{NH}_{4}-\mathrm{N}$ for which a part of $\mathrm{NH}_{4}-\mathrm{N}$ is assimilated for proliferation [31] and the other portion is further converted into intermediates $\mathrm{NO}_{2}-\mathrm{N}$ and $\mathrm{NO}_{3}-\mathrm{N}$.

The presence of $\mathrm{NO}_{3}-\mathrm{N}$ can induce denitrification enzymes production thus resulting in the initiation of the denitrification process which involves the conversion of $\mathrm{NO}_{3}-\mathrm{N}$ denoted as $\mathrm{M}_{3}$ into nitrogenous gas $\left(\mathrm{N}_{2}\right)$ denoted as $\mathrm{P}_{1}$. Under optimized conditions, it has been shown that when the biomass is provided with $\mathrm{NH}_{4}-\mathrm{N}$ and $\mathrm{CN}^{-}$it undergoes multiphase growth while simultaneously degrading the pollutants. Therefore, the predictive capability of cybernetic models was evaluated to estimate the simultaneous degradation of $\mathrm{NH}_{4}-\mathrm{N}$ and $\mathrm{CN}^{-}$using the cyanide degrading bacteria $A$. courvalinii. The model was developed based on the metabolic reaction network as illustrated in Fig. 1.

All these processes are catalysed by specific enzymes, i.e. ammonia monooxygenase (AMO), nitrate reductase (NaR), and nitrite reductase (NiR). When modelling metabolic networks, two vectors are considered important for cybernetic variables. These vectors are and $v$, for which is a fractional allocation of resources needed for enzyme synthesis, such that $\sum_{i-1}^{n_{i}} u_{i}=1$ and with $v$ representing the activity of the different enzymes. Conditions $0 \leq u_{i}, v_{i} \leq 1$, whereby. $i=1,2,3,4$. $u$ is needed for balancing the reaction. For example, when the maximum synthesis rate $r_{E}$ for enzyme $E_{i}$ is regulated then $u_{i}=r_{E_{i}}$. Moreover, $v_{i}$ is required to estimate the regulated reaction rates; thus, $r_{i}$ will be the rate of the $i^{\text {th }}$ reaction when enzyme $E_{i}$ is fully active. The regulated $i^{\text {th }}$ reaction can also be written as $r=v_{r} r_{i}$.

Monods' model was used to express the rate of TN removal $\left(r_{i}\right)$ for pollutant $S_{i}$ and $S_{j}$ catalysed by enzyme $e_{i}$ to form intermediate $M_{2}$ and $M_{3}$ (Eq. (4)).

$$
r_{i}=r_{i}^{\max } \frac{S}{S+K_{i}}\left(\frac{e_{1}}{e_{i}^{\max }}\right) \quad i=1,2,3,4 \text { and } S=S_{i}, S_{j}
$$

The cell growth rate $\left(r_{g}\right)$ was model using rate law equation $\left(1^{\text {st }}\right.$ order) as indicated in Eq. (5).

$$
r_{g}=\mu_{g} X
$$

Where $r_{i}^{\max }$ is the are maximum pollutant removal rate and $K_{i}$ is the pollutant saturation constant, while $X$ is cell concentration and $\mu_{g}$ is the cell-specific growth rate.

Enzyme synthesis for the two pollutants, $S_{1}$ and $S_{2}$ was assumed to be maximized as the growth rate of biomass increased such that (Eq. (6));

$$
u=\frac{r_{i} / M_{i}}{\sum_{j=1}^{2} r_{j} / M_{i}} \quad v=\frac{r_{i} / M_{i}}{\max \left(r_{i} / M_{i}\right)} \quad i=1,2,3,4
$$

It was hypothesised that $\mathrm{NH}_{4}-\mathrm{N}$ was broken down into $\mathrm{NO}_{2}-\mathrm{N}$ via AMO (represented by $e_{2}$ ) catalysis while $\mathrm{CN}^{-}$was decomposed by cyanide degrading enzyme(s) represented as $e_{1}$. The intermediate $\mathrm{NO}_{2}-\mathrm{N}$ was further broken down into $\mathrm{NO}_{3}-\mathrm{N}$ facilitated by $\mathrm{NiR}$ represented in the diagram as $e_{3}$, with $\mathrm{NO}_{3}-\mathrm{N}$ being further decomposed into $\mathrm{N}_{2}$ by NaR represented as $e_{4}$. The model, Eq. (7) would thus represent the rate of enzyme(s) synthesis responsible for the $\mathrm{SNaD}$ under cyanogenic conditions.

$$
\frac{d e_{i}}{d t}=\alpha_{e i}+r_{e i} u_{i}-\left(D_{g}+b_{i}\right) e_{i} \quad i=1,2,3,4
$$

Where $\left(\frac{d e_{i}}{d t}\right)$ is the rate of enzyme(s) synthesis, while $\alpha_{e i}$ represents an inductive rate, $b_{i}$ the activity of the enzyme responsible for decomposition of a pollutant, $r_{e i}$ the decomposition rate of the nitrogenous pollutant, $b_{i}$ is the degradation rate constant of the enzyme, $D_{g}$ dilution term due to growth rate. All these model parameters were estimated by polymath software v6.0 using experimental data.

\section{Results and Discussion}

\subsection{Predictive Ability of Response Surface Methodology}

\subsubsection{Analysis of variance (ANOVA) for TN removal}

The central composite design was used to study the interaction between the independent variables, $\mathrm{pH}$ and temperature, that affect $\mathrm{SNaD}$ for TN removal. Table 1 shows analysis of variance (ANOVA) of the quadratic model used to describe TN removal. The model F-value of 17.01 for TN removal was higher than 1.0, which indicated that the variation between the model and experimental data was higher.

The predicted values of the RSM were compared with the experimental values, with the p-value being 0.0009 for the model, which is smaller than the alpha level of 0.05 . This meant that there was a consequential relationship between the predicted values and the actual values of TN removal. However, other parameters such as the deviation of the model values from the actual data points (standard deviation), $\mathrm{R}^{2}$, adjusted $\mathrm{R}^{2}$, and predicted $\mathrm{R}^{2}$ need to be considered to judge the adequacy of the model - see Table 1 .

The quadratic model was also used to predict $\mathrm{SNaD}$ under $\mathrm{CN}$ conditions. The significance of the parameters was determined using values of "Prob > F" less than 0.05, thus, in this case, A, A2, and B2 were found to be significant for the model. Therefore, the model was improved by reducing it from Eq. (8) to Eq. (9).

$$
\begin{gathered}
\mathrm{TN} \text { removal }=78.57-12.08 \mathrm{~A}-8.88 \mathrm{~B}+ \\
4.21 \mathrm{AB}-28.27 \mathrm{~A} 2-30.41 \mathrm{~B} 2
\end{gathered}
$$

$$
\mathrm{TN} \text { removal }=78.57-12.08 \mathrm{~A}-28.27 \mathrm{~A} 2-30.41 \mathrm{~B} 2
$$

The visualization of the predicted model was obtained using a surface response plot - see Fig. 3. In this study, the response was set to maximize the degradation efficiency of $\mathrm{TN}$ in a $\mathrm{SNaD}$ system that contains multiple nitrogenous sources, i.e $\mathrm{NH}_{4}-\mathrm{N}$, 
Environmental Engineering Research 26(6) 200346

Table 1. Analysis of Variance (ANOVA) of the Quadratic Parameters for SNaD Process Used for TN Removal under CN- Conditions

\begin{tabular}{|c|c|c|c|c|c|c|}
\hline Source & Sum of Squares & df & Mean Square & F-value & p-value & \\
\hline Model & $12,482.87$ & 5 & 2496.57 & 17.01 & 0.0009 & significant \\
\hline A-Temperature & $1,167.65$ & 1 & 1167.65 & 7.96 & 0.0257 & \\
\hline B-pH & 631.10 & 1 & 631.10 & 4.30 & 0.0768 & \\
\hline $\mathrm{AB}$ & 70.78 & 1 & 70.78 & 0.4824 & 0.5097 & \\
\hline $\mathrm{A}^{2}$ & $5,558.29$ & 1 & 5558.29 & 37.88 & 0.0005 & \\
\hline $\mathrm{B}^{2}$ & $6,434.58$ & 1 & 6434.58 & 43.85 & 0.0003 & \\
\hline Residual & $1,027.19$ & 7 & 146.74 & & & \\
\hline Lack of Fit & $1,027.19$ & 3 & 342.40 & & & \\
\hline Pure Error & 0.0000 & 4 & 0.0000 & & & \\
\hline Cor Total & $13,510.06$ & 12 & & & & \\
\hline
\end{tabular}

$\mathrm{NO}_{2}-\mathrm{N}$, and $\mathrm{NO}_{3}-\mathrm{N}$, with $\mathrm{CN}^{-}$as a secondary nitrogenous source or pollutant. A. courvalinii was found to remove up to $78.6 \%$ of $\mathrm{TN}$ via $\mathrm{SNaD}$ from an initial concentration of $20 \mathrm{mg} \mathrm{NH}-\mathrm{N} / \mathrm{L}$ within 5 $\mathrm{h}$ of incubation. Li et al. [32] reported that Pseudomonas stutzeri YZN-001 could remove $\mathrm{NH}_{4}-\mathrm{N}$ at $37{ }^{\circ} \mathrm{C}$ rapidly; however, the removal of $\mathrm{NO}_{2}-\mathrm{N}$ and $\mathrm{NO}_{3}-\mathrm{N}$ only occurred at $30^{\circ} \mathrm{C}$.

The surface plot for TN removal under cyanogenic conditions as shown in Fig. 3, indicated that the maximum operational efficiency for the $\mathrm{SNaD}$ containing $\mathrm{CN}^{-}$was located inside the experimental region. This was a confirmation of the optimum being 6.5 and $36.5^{\circ} \mathrm{C}$. Moreover, the plateau in surface response plots in Fig. 3 indicated the suitability of operational conditions for $\mathrm{SNaD}$, it also highlighted that the lowest degradation efficiency for TN removal and $\mathrm{CN}^{-}$degradation was observed at temperature and $\mathrm{pH}$ of $40.04^{\circ} \mathrm{C}$ and 6.5 with degradation efficiencies of approximately $5 \%$. When the temperature is $36.5{ }^{\circ} \mathrm{C}$ with $\mathrm{pH}$ being 2.9 or 10.0 the degradation efficiency for TN removal was found to be 46.1 and $5.6 \%$, respectively. This indicated that changes in $\mathrm{pH}$ and temperature affect TN removal.

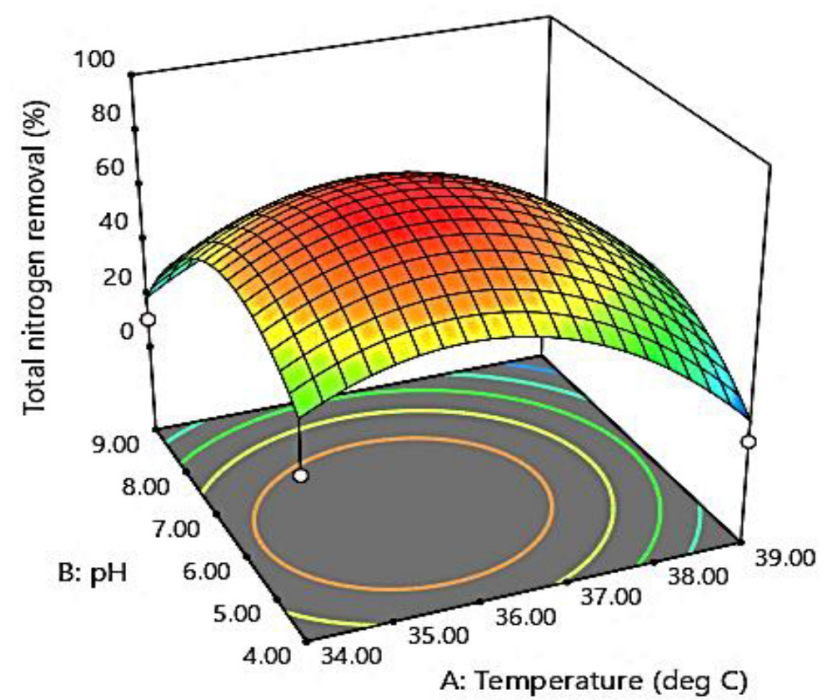

Fig. 3. Surface response plot showing the interaction between $\mathrm{pH}$, Temperature, and $\mathrm{TN}$ removal.

\subsubsection{Batch reactor experiment and model simulations}

To generate data for the models, removal (degradation) kinetics of $\mathrm{TN}$ were studied at optimized conditions in $1 \mathrm{~L}$ reactors. The initial (higher) concentration of $40 \mathrm{mg} \mathrm{CN} / \mathrm{L}$ and $250 \mathrm{mg} \mathrm{NH}_{4}-\mathrm{N} / \mathrm{L}$ were used and the experiment was conducted for $264 \mathrm{~h}$. The results indicated that up to $70.5 \%$ of $\mathrm{TN}$ was removed within 264 h, see Fig. 4(a). A. courvalinii was shown to possess distinctly different attributes involving the simultaneous removal/ or degradation of $\mathrm{TN}$ and $\mathrm{CN}^{-}$, which is an indication of the complete elimination of inhibitory effects of $\mathrm{CN}^{-}$compound towards $\mathrm{SNaD}$ used for TN reduction in wastewaters. Duan et al. [33] reported that a nitrification efficiency of $91.82 \pm 1.98 \%$ after $42 \mathrm{~h}$ by Vibrio diabolicus SF16 was achievable in a system that does not contain $\mathrm{CN}^{-}$.

Furthermore, He et al. [10] also reported an $\mathrm{NH}_{4}-\mathrm{N}$ removal efficiency of $93.6 \%$ after $96 \mathrm{~h}$ of incubation with Pseudomonas tolaasii Y-11; albeit, the utilization of pollutants by a specific species might be sequential, with the organism utilizing the easily biodegradable pollutant with a less complex structure first, subsequent to the degradation of the second less desirable pollutants which sometimes results in multi-phased growth of the organism(s) used. The cell concentration was also studied and modelled (Fig. 4(a)).

The data points of predicted growth rate versus actual growth rate were scattered, with numerous outliers from the trend line (Fig. 4(b)) which signifies that the first-order equation did not adequately represent the growth model with the variance being $4.75 \times 10^{9}$ and a standard deviation of $6.89 \times 10^{4}$ and low $\mathrm{R}^{2}$ of 0.5303 indicating a poor prediction of the growth. Song and Lui [34] also reported that simulation of cybernetic model adequately matches with the biomass proliferation profile of Acidovorax sp. and P. denitrificans. This lack of fit was associated with other factors that were not considered by the model such as the inhibition of the microbial growth by metabolic by-products. Overall, the microorganism used in this study primarily degraded $\mathrm{TN}$ including $\mathrm{CN}^{-}$simultaneously, which is an interesting trait considering that $\mathrm{CN}^{-}$is a known inhibitor to nitrification, with as little as $1 \mathrm{mg} \mathrm{CN}^{-} / \mathrm{L}$ completely inhibiting nitrification [5]. 

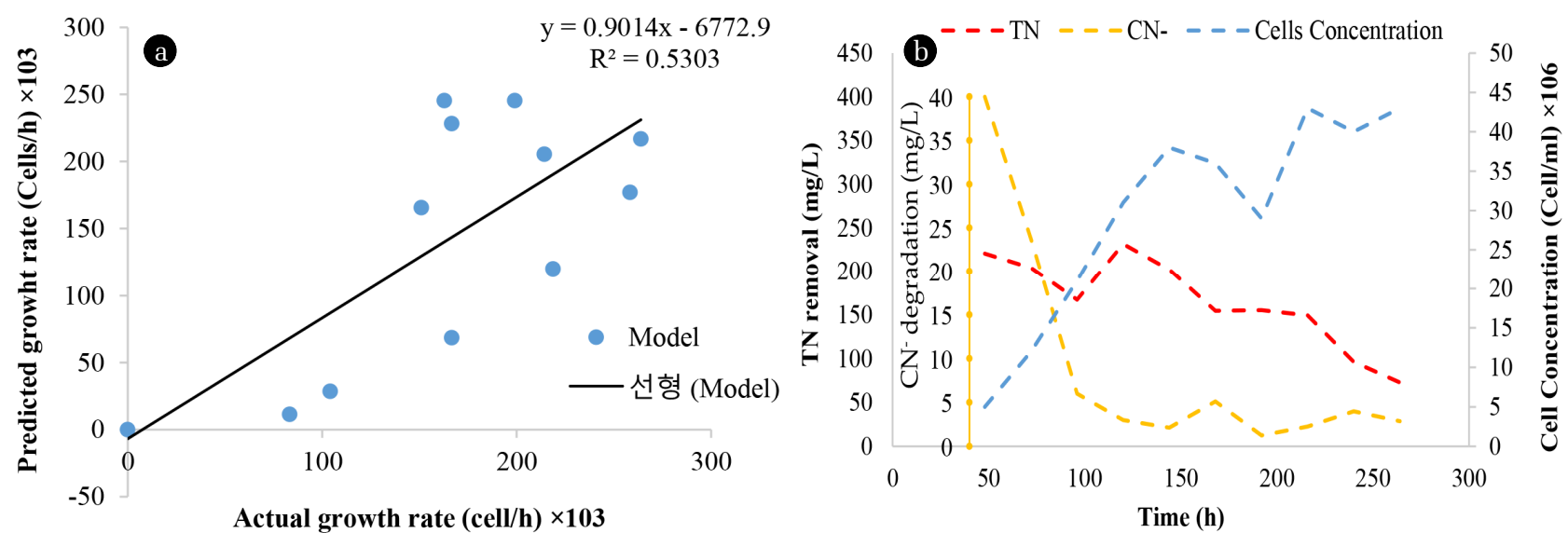

Fig. 4. Degradation kinetics of $\mathrm{TN}$ and cyanide in a batch culture reactor. $\mathrm{A}$ : $\mathrm{TN}$ and $\mathrm{CN}^{-}$degradation and cell concentration over time. B: model fitting into biomass plot.

\subsection{Prediction Ability of RSM in Comparison to Cybernetic Models}

When comparing modeled and actual $\mathrm{SNaD}$ performance under optimum conditions, the correlation coefficient $\left(\mathrm{R}^{2}\right)$ of 0.92 was observed; although this high $\mathrm{R}^{2}$ was observed, $\mathrm{R}^{2}$ alone cannot verify whether the model is adequate or not, since $R^{2}$ can improve with the extension of dependent variables scale regardless of whether the variable is significant or not. Thus the adjusted $R^{2}(0.87)$ and predicted $R^{2}(0.46)$ were considered (Table S3). Adjusted $R^{2}$ is normally used to compare the explanatory power of a regression model, while the Adjusted $\mathrm{R}^{2}$ only account for variables that improve the model; therefore, the addition of less significant variables decreases the Adjusted $\mathrm{R}^{2}$. Overall, the Adjusted $\mathrm{R}^{2}$ is considered more reliable compared to the correlation coefficient.

Hence, the Adjusted $\mathrm{R}^{2}$ was used to evaluate the adequacy of the model culminating in the selection of a suitable model describing $\mathrm{SNaD}$ for TN removal under $\mathrm{CN}^{-}$conditions. As the Adjusted $\mathrm{R}^{2}$ of 0.87 was higher; therefore, the model was deemed adequate. However, the difference between predicted $R^{2}$ and adjusted $R^{2}$ was above 0.2 , indicating that there would be challenges with the use of the model. Hence, the model was reduced to expression as highlighted in Eq. (7).

This was further confirmed by the average standard deviation (12.11) for TN removal with a standard error (SE) of 5.284 (Table S3). The SE for TN removal indicated that the RSM model could be improved to represent the experimental data more adequately. The parity plot for TN removal was used to compare the predicted TN removal efficacy and the actual TN removal efficiency. The data points of the RSM model deviated from the trendline indicating a larger deviation of the data points from the trend line.

Cybernetic models were developed to predict maximum pollutant utilization rates which are presented as $S_{1}$ and $S_{2}$ for TN and $\mathrm{CN}^{-}$, respectively via catalysis by numerous enzymes. A cybernetic model was simulated by estimating unknown parameters using experimental data as listed in Table 2. The model successfully described the rate of TN removal with $\left(\mathrm{R}^{2}\right.$ of 0.97 , indicating a 97\% suitability. Moreover, the Adjusted determination coefficient (Adj $\mathrm{R}^{2}=0.96$ ) was very high with the difference between $\mathrm{R}^{2}$
Table 2. Model Parameter Estimations

Fitting constants and the values of kinetic parameters ( $\pm 95 \%$ confidence interval)

\begin{tabular}{lc}
\hline Parameters & Value \\
\hline$r_{i}^{\max }$ & $0.02 \mathrm{mg} / \mathrm{g} \cdot \mathrm{h}$ \\
$K_{i 1}$ & $2.91 \mathrm{mg} / \mathrm{L}$ \\
$\alpha_{e 1}$ & $0.89 \mathrm{mg} / \mathrm{g} \cdot \mathrm{h}$ \\
$\alpha_{e 2}$ & $1.42 \mathrm{mg} / \mathrm{g} \cdot \mathrm{h}$ \\
$\alpha_{e 3}$ & $0.29 \mathrm{mg} / \mathrm{g} \cdot \mathrm{h}$ \\
$\alpha_{e 4}$ & $0.03 \mathrm{mg} / \mathrm{g} \cdot \mathrm{h}$ \\
$r_{e 1}$ & $30.42 \mathrm{mg} / \mathrm{g} \cdot \mathrm{h}$ \\
$r_{e 2}$ & $791.97 \mathrm{mg} / \mathrm{g} \cdot \mathrm{h}$ \\
$r_{e 3}$ & $454.71 \mathrm{mg} / \mathrm{g} \cdot \mathrm{h}$ \\
$r_{e 4}$ & $0.11 \mathrm{mg} / \mathrm{g} \cdot \mathrm{h}$ \\
$b_{1}$ & $0.76 \mathrm{mg} / \mathrm{g} \cdot \mathrm{h}$ \\
$b_{2}$ & $20.29 \mathrm{mg} / \mathrm{g} \cdot \mathrm{h}$ \\
$b_{3}$ & $227.64 \mathrm{mg} / \mathrm{g} \cdot \mathrm{h}$ \\
$b_{4}$ & $0.01 \mathrm{mg} / \mathrm{g} \cdot \mathrm{h}$ \\
$r_{g}$ & $0.001 \mathrm{Cell} / \mathrm{L} / \mathrm{h}$ \\
\hline
\end{tabular}

and the Adj $\mathrm{R}^{2}$ being 0.006 . This difference is minute; therefore, it advocated for the high significance of the model.

Furthermore, the variance (0.012), standard error (0.0035) and standard deviation (0.047) for TN removal were low, demonstrating that there's an insignificant difference between the predicted values from the model and the actual experimental values. Although the RSM model was shown to adequately represent TN removal, the adjusted $\mathrm{R}^{2}$ of the cybernetic model was higher than that of the RSM model. Thus, cybernetic models were selected as the best model to predict TN removal using SNaD. Song and Liu. [34] also reported a better prediction of denitrification by a cybernetic model compared to a simple kinetic model. This proves that biological processes such as TN removal must be predicted using metabolic 

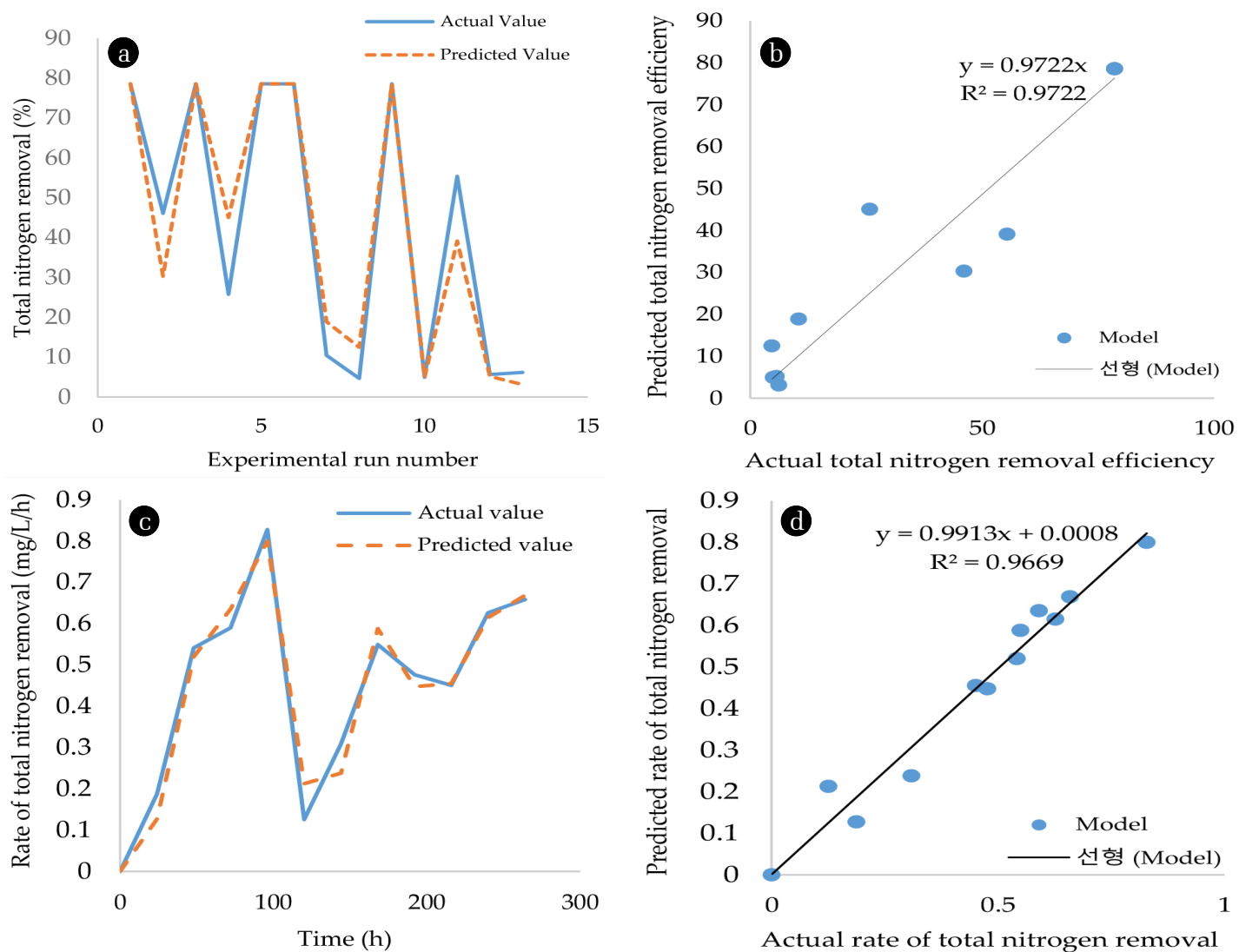

Fig. 5. A comparison of the prediction ability of RSM and cybernetic models. (a) prediction of TN removal efficiency by RSM model; (b) parity plot comparing predicted total nitrogen removal efficiency and actual total nitrogen removal efficiency by RSM; (c) Rate of TN removal predicted by cybernetic model; (d) parity plot for comparing the predicted rate of TN removal with the actual rate of TN removal by cybernetic model.

network modelling that takes into account the metabolic functions of the microbial population involved in the process. Furthermore, the parity plot for RSM and the cybernetic model were compared. The parity plot of the cybernetic model had data points scattered closer to the trend line as opposed to the RSM model which numerous outliers showing a significant deviation from the trend line (Fig. 5(b) and (d)), supporting the statement that the cybernetic model better-predicted $\mathrm{TN}$ removal better in $\mathrm{CN}^{-}$using $\mathrm{SNaD}$.

\section{3. $\mathrm{TN} / \mathrm{CN}$ - Biocatalysis}

$\mathrm{SNaD}$ involves a process whereby $\mathrm{NH}_{4}-\mathrm{N}$ is converted into $\mathrm{NO}_{2}-\mathrm{N}$ and further to $\mathrm{NO}_{3}-\mathrm{N}$ which activates the production of denitrification enzymes that convert $\mathrm{NO}_{3}-\mathrm{N}$ into $\mathrm{N}_{2}$. Enzyme activity was determined by extracting free-cell enzymes supplemented into solutions consisting of pollutants, $\mathrm{NH}_{4}-\mathrm{N}$, and $\mathrm{CN}^{-}$. The decrease in the pollutants and the accumulation of the intermediates $\mathrm{NO}_{3}-\mathrm{N}$ and $\mathrm{NO}_{2}-\mathrm{N}$ were observed (Fig 6(a)-(f)). The decrease in $\mathrm{NH}_{4}-\mathrm{N}$ and $\mathrm{CN}^{-}$was slow in the first two minutes of the reaction with a degradation rate of 0.83 and $1.1 \mathrm{mg} / \mathrm{L} / \mathrm{min}$, respectively.

The degradation rates increased after the fourth minute, with the rate increasing up to 1.64 and $1.73 \mathrm{mg} / \mathrm{L} / \mathrm{min}$ being observed, respectively; albeit, the rate of degradation decreased after 5 min.
Since the degradation was conducted at ambient temperature to simulate real-life WWTP conditions, the decrease in the pollutants indicated the presence of $\mathrm{TN}$ and $\mathrm{CN}^{-}$degrading enzymes; moreover, the increase and decrease of intermediates $\mathrm{NO}_{2}-\mathrm{N}$ and $\mathrm{NO}_{3}-\mathrm{N}$ indicated the presence of denitrification enzymes; hence, the isolated microorganisms were deemed to be capable to carry-out $\mathrm{SNaD}$ even in the presence of $\mathrm{CN}$. The enzyme synthesis model successfully described individual enzyme activity with $\mathrm{R}^{2}$ above 0.7 indicating a good fit of the activity models. Hamilton et al [35] also reported that enzyme biosynthesis based models are better predictors of microbial growth, which supports the results obtained from this study whereby it was shown that the cybernetic model is a better predictor of multiple nitrogenous source utilization such as $\mathrm{CN}^{-}$ and $\mathrm{TN}$ in systems such as $\mathrm{SNaD}$.

\subsection{Overall Remarks about the Study}

The results obtained from this study indicated that the inhibition effect of $\mathrm{CN}^{-}$towards $\mathrm{SNaD}$ can be completely eradicated by using cyanide degrading microorganism(s) for $\mathrm{SNaD}$ systems, provided that appropriate operational conditions are established. This eliminates the necessity of using a pre-treatment reactor for $\mathrm{CN}^{-}$removal, thus, lowering operational costs. Additionally, these findings pro- 

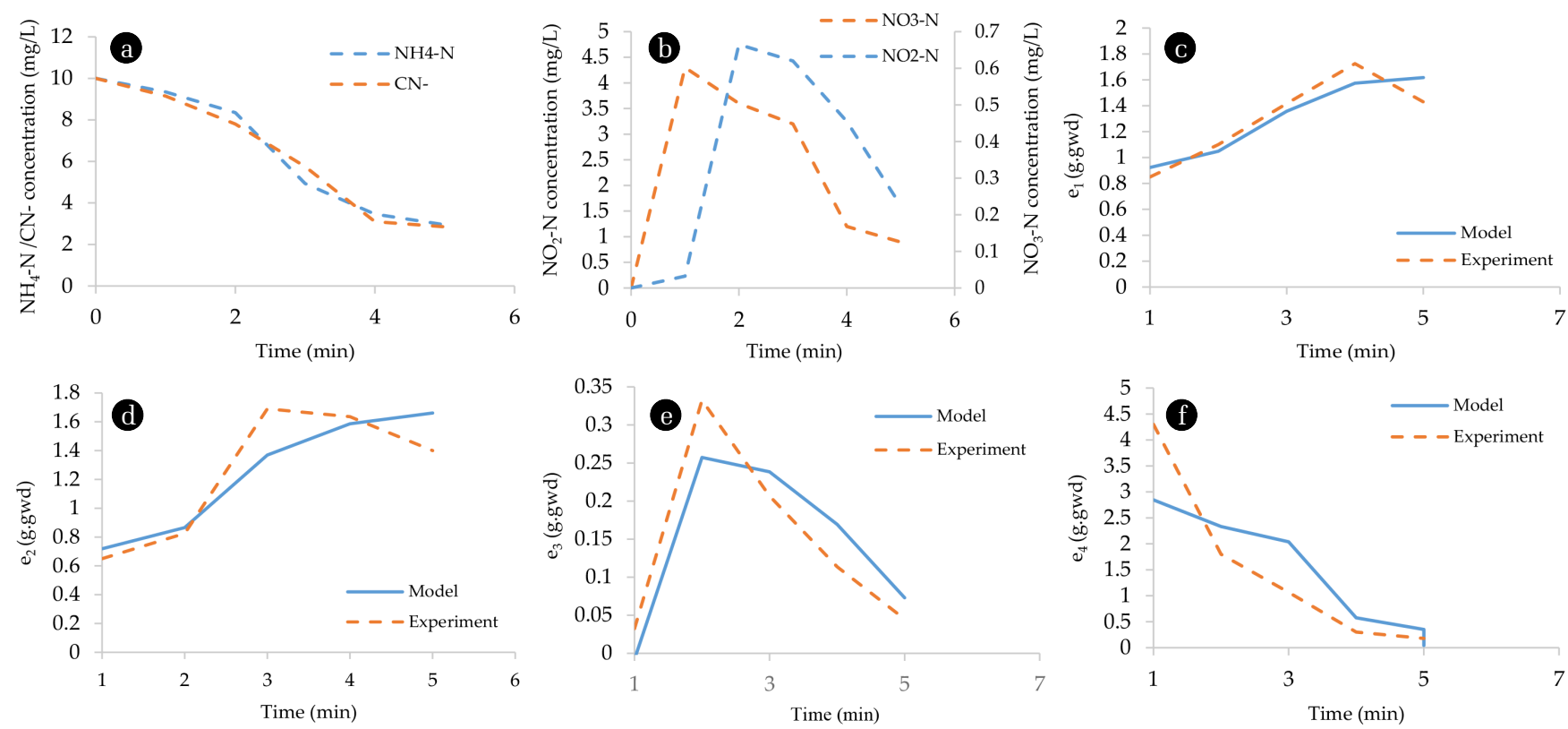

Fig. 6. (a) $\mathrm{NH}_{4}-\mathrm{N}$ and $\mathrm{CN}$ - removal/ degradation. (b) $\mathrm{NO}_{2}-\mathrm{N}$, and $\mathrm{NO}-\mathrm{N}$ removal simulation of the cybernetic model. (c) level of key enzyme $\mathrm{e}_{1}$ over time. (d) level of key enzyme $\mathrm{e}_{2}$ over time. (e) level of key enzyme $\mathrm{e}_{3}$ over time. (f) level of key enzyme $\mathrm{e}_{4}$.

vide a sustainable solution towards inhibition reduction of $\mathrm{SNaD}$ in large-scale WWTPs. The RSM and cybernetic models were compared for their ability to predict $\mathrm{SNaD}$ performance even in the presence of inhibitors such as $\mathrm{CN}^{-}$, which is known as a highly potent toxicant. The findings indicated that the cybernetic modeling adapted from metabolic networking provides an approach that is a robust and novel predictor of $\mathrm{SNaD}$ under inhibitory conditions, even when novel hybridized models, useful for process control of $\mathrm{SNaD}$, are used.

\section{Conclusion}

Response surface methodology was used to determine the optimum conditions for $\mathrm{TN}$ removal under $\mathrm{CN}^{\top}$ conditions using $A$. courvalinii, a $\mathrm{CN}^{-}$tolerant bacterium with $\mathrm{TN}$ removal capabilities in $\mathrm{SNaD}$. The optimum $\mathrm{pH}$ and temperature were found to be 6.5 and $36.5^{\circ} \mathrm{C}$, with degradation efficiency of $78.6 \%$ for $\mathrm{TN}$ and a significant (80.2\%) for $\mathrm{CN}^{-}$degradation, respectively. Moreover, cybernetic modeling was found to be better at predicting $\mathrm{SNaD}$ under cyanogenic conditions with a higher adjusted $\mathrm{R}^{2}(0.96)$ as opposed to the RSM models with an adjusted $\mathrm{R}^{2}$ of 0.87 . The cybernetic models used in this study were simplified; thus they do not provide illuminating insights into cellular responses. Hence, additional experiments are needed to elucidate metabolic flux distributions better and to further develop models for $\mathrm{SNaD}$ process prediction as well as optimisation.

\section{Acknowledgments}

This study was supported by the University Research Fund (URF RK16) at the Cape Peninsula University of Technology.

\section{Author Contributions}

N.M. (Ph.D) conducted all the experiment and wrote the paper. E.I.O. (Ph.D) interpreted data and revised the manuscript. L.C.R. (Ph.D) interpreted data and revised the manuscript. B.S.C. (Ph.D) interpreted data and revised the manuscript. S.K.O.N. (Associate Professor) interpreted data, acquired funding and editing the manuscript.

\section{References}

1. Van Dedem G, Moo-Young MA. Model for diauxic growth. Biotechnol. Bioeng. 1975;17:1301-1312.

2. Narang A, Pilyugin S. Bacterial gene regulation in diauxic and non-diauxic growth. J. Theor. Biol. 2007;244:326-348.

3. Solopova A, van Gestel J, Weissing F, et al. Bet-hedging during bacterial diauxic shift. Proc. Natl. Acad. Sci. USA 2014;111: 7427-7432.

4. Chen P, Li J, Li QX, et al. Simultaneous heterotrophic nitrification and aerobic denitrification by bacterium Rhodococcus sp. CPZ24. Bioresour. Technol. 2012;116:266-270.

5. Kim Y, Park D, Lee D, Park J. Inhibitory effects of toxic compounds on nitrification process for cokes wastewater treatment. J. Hazard. Mater. 2008;152:915-921.

6. Zhang Y, Shi Z, Chen M, Dong X, Zhou J. Evaluation of simultaneous nitrification and denitrification under controlled conditions by an aerobic denitrifier culture. Bioresour. Technol. 2015;175:602-605

7. Jin R, Liu T, Liu G, Zhou J, Huang J, Wang A. Simultaneous heterotrophic nitrification and aerobic denitrification by the marine origin bacterium Pseudomonas sp ADN-42. Appl. 
Biochem. Biotechnol. 2015;175:2000-2011.

8. He T, Li Z, Sun Q, Xu Y, Ye Q. Heterotrophic nitrification and aerobic denitrification by Pseudomonas tolaasii Y-11 without nitrite accumulation during nitrogen conversion. Bioresour. Technol. 2016;200:493-499

9. Choi OK, Hu ZQ. Nitrification inhibition by silver nanoparticles. Water Sci. Technol. 2009;59:1699-1702.

10. Papirio S, Zou G, Ylinen A, Di Capua F, Pirozzi F, Puhakka JA. Effect of arsenic on nitrification of simulated mining water. Bioresour. Technol. 2014;164:149-154

11. Ma Q, Qu Y, Shen W, et al. Bacterial community compositions of coking wastewater treatment plants in steel industry revealed by Illumina high-throughput sequencing. Bioresour. Technol. 2015;179:436-443.

12. Singh N, Balomajumder C. Simultaneous removal of phenol and cyanide from aqueous solution by adsorption onto surface modified activated carbon prepared from coconut shell. J. Water Process. Eng. 2016;9:233-245

13. Feng C, Huang L, Yu H, Yi X, Wei C. Simultaneous phenol removal, nitrification and denitrification using microbial fuel cell technology. Water Res. 2015;76:160-170.

14. Carrera J, Baeza J, Vicent T, Lafuente J. Biological nitrogen removal of high-strength ammonium industrial wastewater with two-sludge system. Water Res. 2003;37:4211-4221.

15. Kim Y, Cho H, Lee D, Park D, Park J. Comparative study of free cyanide inhibition on nitrification and denitrification in batch and continuous flow systems. Desalination 2011a;279: 439-444.

16. Kim Y, Lee D, Park C, Park D, Park J. Effects of free cyanide on microbial communities and biological carbon and nitrogen removal performance in the industrial activated sludge process. Water Res. 2011b;45:1267-1279.

17. Cui J, Wang X, Yuan Y, Guo X, Gu X, Jian L. Combined ozone oxidation and biological aerated filter processes for treatment of cyanide containing electroplating wastewater. Chem. Eng. 2014;241:184-189.

18. Han Y, Jin X, Wang Y, Liu Y, Chen X. Inhibitory effect of cyanide on nitrification process and its eliminating method in a suspended activated sludge process. Environ. Sci. Pollut. Res. Int. 2014;21:2706-2713.

19. Mpongwana N, Ntwampe SKO, Omodanisi EI, Chidi BS, Razanamahandry LC. Sustainable approach to eradicate the inhibitory effect of free-cyanide on simultaneous nitrification and aerobic denitrification during wastewater treatment. Sustainability 2019;11:6180 .

20. Han Y, Jin X, Wang F, Liu Y, Chen X. Successful startup of a full-scale acrylonitrile wastewater biological treatment plant (ACN-WWTP) by eliminating the inhibitory effects of toxic compounds on nitrification. Water Sci. Technol. 2013;69:553559.

21. Park D, Lee D, Kim Y, Park J. Bioaugmentation of cyanide-degrading microorganisms in a full-scale cokes wastewater treatment facility. Bioresour. Technol. 2008;99:2092-2096.

22. Han Y, Jin X, Wang Y, Liu Y, Chen X. Inhibitory effect of cyanide on nitrification process and its eliminating method in a suspended activated sludge process. Environ. Sci. Pollut. Res. 2013;21:2706-2713.

23. Ojaghi A, Tonkaboni SZS, Shariati P, Ardejani FD. Novel cyanide electro-biodegradation using Bacillus pumilus ATCC 7061 in aqueous solution. J. Environ. Health. Sci. eng. 2018;16:99-108.

24. Kandasamy S, Dananjeyan B, Krishnamurthy K, Benckiser G. Aerobic cyanide degradation by bacterial isolates from cassava factory wastewater. Braz. J. Microbiol 2015;46:659-666.

25. Luque-Almagro VM, Moreno-Vivián C, Roldán MD. Biodegradation of cyanide wastes from mining and jewellery industries. Curr. Opin. Biotechnol. 2016;38:9-13.

26. Mpongwana N, Ntwampe S, Mekuto L, Akinpelu E, Dyantyi $\mathrm{S}$, Mpentshu Y. Isolation of high-salinity-tolerant bacterial strains, Enterobacter sp, Serratia sp, Yersinia sp, for nitrification and aerobic denitrification under cyanogenic conditions. Water Sci. Technol. 2016;73:2168-75179.

27. Mpongwana N. Metabolic network modelling of nitrification and denitrification under cyanogenic conditions [dissertation]. South Africa: Cape Peninsula University of Technology; 2019. http://hdl.handle.net/20.500.11838/2982

28. Stephen FA, Thomas LM, Alejandro AS, et al. Gapped BLAST and PSI-BLAST: a new generation of protein database search programs. Nucleic Acids Res. 1997;25:3389-3402.

29. Mekuto L, Ntwampe SKO, Jackson VA. Biodegradation of free cyanide and subsequent utilisation of biodegradation by-products by Bacillus consortia: optimisation using response surface methodology. Environ. Sci. Pollut. Res. Int. 2015;22:10434-10443.

30. Mpongwana N, Ntwampe SK, Mekuto L, Akinpelu EA, Dyantyi $\mathrm{S}$, Mpentshu Y. Isolation of high-salinity-tolerant bacterial strains, Enterobacter sp., Serratia sp., Yersinia sp., for nitrification and aerobic denitrification under cyanogenic conditions. Water Sci. Technol. 2016;73:2168-2175.

31. Kanyenda G, Ntwampe SKO, Mpongwana N, Godongwana B. Mathematical exposition of simultaneous nitrification and aerobic denitrification. In: Proceedings of the 10th lnt'I Conference on Advances in Science, Engineering, Technology \& Healthcare (ASETH-18);19-20 November 2018; Cape Town, South Africa. p. 19-20.

32. Li C, Yang J, Wang X, et al. Removal of nitrogen by heterotrophic nitrification-aerobic denitrification of a phosphate accumulating bacterium Pseudomonas stutzeri YG-24. Bioresour. Technol. 2015;182:18-25.

33. Duan J, Fang H, Su B, Chen J, Lin J. Characterization of a halophilic heterotrophic nitrification-aerobic denitrification bacterium and its application on the treatment of saline wastewater. Bioresour. Technol. 2015;179:421-428.

34. Song HS, Liu C. Dynamic metabolic modelling of denitrifying bacterial growth: the cybernetic approach. Ind. Eng. Chem. Res. 2015;54:10221-10227.

35. Hamilton R, Casasús A, Rasche M, Narang A, Svoronos SA, Koopman B. Structured model for denitrifier diauxic growth. Biotechnol. Bioeng. 2005;90:501-508. 